Dossiê: Desafios teológicos do Pluralismo Religioso - Artigo original (c) (i)

\title{
Pela transversalidade do diálogo inter-religioso na teologia e na pastoral
}

\section{Transversality in the inter-religious dialogue in theology and pastoral}

\author{
Wagner Lopes Sanchez*
}

\begin{abstract}
Resumo:
No âmbito das relações da igreja católica com as religiões, a ruptura com o modelo de cristandade efetivada pelo Concílio teve um papel decisivo: significou uma guinada importante que levou a uma revisão não só dessas relações com as religiões, mas também da própria visão de igreja e da teologia. Com isso, o Concílio deu um grande passo ao lançar um olhar positivo sobre as religiões e reconhecer que elas contêm "sementes do Verbo" ( $A G$ 11b). No entanto, é preciso reconhecer que os padres conciliares se limitaram a apresentar diretrizes gerais e indicações de atitudes fundamentais quanto às outras religiões, sem se preocuparem em apresentar uma teologia do diálogo inter-religioso. Este artigo procura problematizar as diretrizes e indicações do Concílio a partir do conceito de transversalidade. Assumimos a perspectiva de que o diálogo inter-religioso, para ser consistente, em consonância com as inspirações conciliares, precisa ser transversal tanto ao discurso como à ação pastoral. A missão, a liturgia, a catequese e a educação teológica são áreas, entre outras, nas quais a transversalidade do diálogo inter-religioso precisa ganhar vida.
\end{abstract}

Palavras-chave: transversalidade; teologia e diálogo inter-religioso.

\begin{abstract}
In the scope of the Catholic Church relationship with religions, the rupture with the Christian model effected by the Councilium had a decisive role: it meant a crucial lurch that led to an inspection of not only the relation with other religions, but also of the ecclesiology and theology. With that, the Concilium took a huge step when casting a positive look on other religions and recognizing they contain "seeds of the Word" (AG 11b). However, it's necessary to acknowledge the concilium priests limited themselves to present general directives and indications of fundamental attitudes regarding other religions, with no concern in presenting an interreligious dialogue theology. This article seeks to problematize the Concilium directives and indications based on the concept of transversality. We took on the perspective that in order for an interreligious dialogue to be consistent, in consonance with the concilium afflatus, it needs to be transversal both in discourse and in the pastoral action. The mission, the liturgy, the catechism and the theological education are areas, amongst others, in which the interreligious dialogue transversality needs to come to life.
\end{abstract}

Keywords: transversability; theology and inter-religious dialogue.

\footnotetext{
Artigo recebido em 22 de junho de 2015 e aprovado em 10 de dezembro de 2015.

* Doutor em Ciências Sociais pela PUC- SP (2001) e professor assistente-doutor na Pontifícia Universidade Católica de São Paulo. País de origem: Brasil. E mail: wagnersanchez@uol.com.br
}

Horizonte, Belo Horizonte, v. 13, n. 40, p. 1982-2008, out./dez. 2015 - ISSN 2175-5841 


\section{Introdução}

Este artigo pretende problematizar o lugar que o diálogo inter-religioso deve ter na vida da igreja católica e, por que não dizer, das igrejas cristãs. Nesse cenário, somos levados a pensar na relevância do diálogo inter-religioso.

A reflexão ensejada neste artigo se baseia em três pressupostos sobre os quais se funda o diálogo inter-religioso: antropológico, teológico e político.

- Pressuposto antropológico: as religiões são uma das formas utilizadas pelos seres para construir sentido para suas vidas. A dimensão do sentido da vida leva os seres humanos a compreenderem a sua existência para além das condições objetivas, concretas. Eles procuram dar sentido, significado e valor a tudo o que fazem no mundo. Essa dimensão está relacionada com uma atitude de confiança em valores que permitem garantir a convivência social. Segundo nomeia essa atitude de fé antropológica (1985, p. 31)1 . O pressuposto antropológico dá ao diálogo inter-religioso o caráter de diálogo entre crenças e valores que são, portanto, imanentes ao ser humano e às culturas.

- Pressuposto teológico: as religiões, nas suas diferentes expressões e apesar de suas contradições e limites, fazem parte das revelações de Deus na história e, por isso, no dizer de Queiruga, são verdadeiras, pois Deus se faz presente em toda a história humana (1997, p. 59-63). As religiões são expressões culturais que manifestam a presença misteriosa do Deus da vida.

- Pressuposto político: o diálogo inter-religioso no mundo globalizado se torna um imperativo da convivência humana. A construção de uma sociedade mais justa passa, necessariamente, pelo diálogo entre as religiões. Por outro lado, se as religiões não dialogarem, a sua credibilidade estará ameaçada.

\footnotetext{
${ }^{1}$ Para esse autor, a fé antropológica é anterior à fé religiosa.
} 
Por ocasião do Concílio Vaticano II, os três pressupostos acima já estavam sendo assumidos pela teologia católica, pelas diversas experiências pastorais e também pelas iniciativas de diálogo com as religiões, que há muito estavam sendo desenvolvidas. Por isso, esses pressupostos estavam presentes no horizonte de reflexão dos padres conciliares.

A partir do Concílio Vaticano II, o tema da teologia das religiões e o tema do diálogo inter-religioso passaram a fazer parte da agenda oficial da igreja católica em resposta a diversas iniciativas, algumas tímidas e outras mais ousadas, que se desenvolveram nas várias igrejas particulares. O Concílio inspirou essas iniciativas e fomentou inclusive o debate no interior da teologia sobre o diálogo com as religiões e suas implicações teóricas e práticas.

A resistência manifestada no percurso do debate conciliar sobre o documento conciliar dedicado às religiões - Declaração Nostra Aetate - era um sinal das dificuldades que o tema das religiões suscitava (WOLFF, 2012, p. 135137). Afinal, era uma resistência secular e de uma posição exclusivista diante das religiões. A reflexão do Concílio e também aquela presente nos documentos pontifícios posteriores estava baseada na teologia do cumprimento e na da presença de Cristo nas religiões. Essa reflexão significou um avanço e estava em sintonia com a dinâmica do diálogo assumida pelo Vaticano II.

Apesar da sua brevidade, a Nostra Aetate expressou muito bem a intenção dos padres conciliares: mudar o paradigma adotado até então pela igreja católica na sua compreensão a respeito das religiões. E isso foi uma grande mudança.

Este artigo retoma essa inspiração e propõe refletir sobre essas questões a partir dos avanços no período pós-Vaticano II. A convicção que está subjacente a este texto é de que é preciso, seguindo as pegadas do Concílio, tornar o tema do diálogo inter-religioso transversal tanto no âmbito da elaboração teológica e do discurso da igreja católica como também em sua prática pastoral. Se o 
ecumenismo foi uma temática transversal aos documentos conciliares (WOLFF, 2015), por que não defender que o diálogo inter-religioso também seja transversal?

Certamente, essa reivindicação coloca desafios bastante arrojados: como fica a questão da "identidade" do catolicismo² ou do cristianismo no diálogo das religiões? Como abrir-se às religiões sem abrir mão daquilo que é fundamental no cristianismo? Quais são as implicações para a comunidade cristã dessa transversalidade do diálogo inter-religioso? Não pretendemos responder a todas essas perguntas, mas propor que o diálogo inter-religioso a ser construído justamente no "canteiro de obras" do encontro das religiões perpasse a teologia, a pastoral e a espiritualidade.

\section{0 conceito de transversalidade: possibilidades para a teologia}

Neste trabalho, utilizamos o conceito de transversalidade para nos referir ao lugar que o diálogo inter-religioso deve ocupar no conjunto da teologia e no conjunto da vida das igrejas cristãs. É necessário, no entanto, explicitar o sentido originário desse conceito. Este conceito é muito utilizado na área da educação, mais especificamente no âmbito das discussões sobre currículo3. Ele é ponto de partida para a uma compreensão do processo pedagógico baseado em temas transversais:

os temas transversais, que constituem o centro das atuais preocupações sociais, devem ser o eixo em torno do qual deve girar a temática das áreas curriculares, que adquirem assim, tanto para o corpo docente como para os alunos, o valor de instrumentos necessários para a obtenção das finalidades desejadas. (MORENO, 2001, p. 37).

\footnotetext{
${ }^{2}$ Muitos grupos conservadores dentro da igreja católica têm insistido na necessidade de defender a identidade católica frente às ameças do mundo moderno. Vigil questiona a prentensão de definir uma identidade cristã, dizendo que "não existe 'a' identidade cristã, não há 'uma' identidade cristã. Não existe diacrônica (ao longo da história) nem sincronicamente (num mesmo momento da história" (VIGIL, 2007, p. 139).

${ }^{3}$ A noção de transversalidade foi desenvolvida por Félix Guattari no início dos anos sessenta (GALLO, s/d, p. 10). Neste texto, interessanos a especifidade dada pela área de educação a essa noção.
} 
Os temas transversais são temas-eixo que perpassam os diversos componentes curriculares e que ganham o status de temas fundamentais. Eles são, assim, temas em torno dos quais os componentes curriculares devem se articular. Desta forma, os componentes curriculares não têm mais fim em si mesmos, mas devem atender aos temas transversais.

Para Bovo, a perspectiva transversal "rompe com o confinamento da atuação dos professores às atividades pedagogicamente formalizadas" e por isso "os temas transversais permeiam toda a prática educativa” (2003, p. 7). Essa perspectiva leva então à superação da concepção tradicional dos diversos componentes curriculares considerados como compartimentos estanques. Isso leva, obviamente, a uma compreensão mais orgânica dos diversos conteúdos e permite que a prática pedagógica se dê de forma mais articulada, atenuando as fronteiras existentes entre os componentes curriculares e o conjunto das atividades desenvolvidas no âmbito escolar.

Como é possível perceber, a perspectiva dos temas transversais ou da transversalidade tem duas implicações: uma de ordem teórica, que altera a compreensão e a abordagem do processo educativo, e outra de ordem prática, que altera a prática educativa e exige que ela seja mais orgânica.

A teologia é uma reflexão que procura responder às grandes questões colocadas pelos crentes e pela sociedade onde eles vivem. Historicamente, a teologia sempre elegeu temas-chave que orientaram a sua reflexão e que também tiveram as duas implicações - teóricas e práticas - acima assinaladas no âmbito da educação. Um exemplo é o tema povo de Deus, no Concílio Vaticano II. Durante muito tempo, um conceito que articulava os grandes temas da teologia foi o de societas perfecta. O Vaticano II abandonou esse conceito e resgatou da tradição cristã mais genuína o conceito de povo de Deus (COMBLIN, 2001, p. 28). Ao resgatar essa noção, o Concílio assumiu a teologia do Povo de Deus e deu a ela lugar de destaque no conjunto dos textos conciliares. A inserção do capítulo II, “O Povo de Deus”, na Constituição Dogmática Lumen Gentium, e antes do capítulo 
que tratou da hierarquia da igreja católica, é um exemplo disso. Esse capítulo apresenta uma teologia do Povo de Deus não só em sintonia com a tradição, mas também com as descobertas das pesquisas teológicas na época e com os avanços pastorais realizados em diversos lugares. A decisão de inserir o capítulo II antes do capítulo sobre a estrutura hierárquica foi uma reviravolta na concepção tradicional e revelou a intenção do Concílio de dar à teologia do Povo de Deus um papel transversal em todos os documentos e, com isso, repercutir na prática pastoral no pós-Concílio (LOPES, 2011)4.

No caso específico do diálogo inter-religioso, quando se afirma que esse tema deve ser transversal5 no fazer teológico e no fazer pastoral, parte-se do pressuposto de que o pluralismo cultural - transfundo do pluralismo religioso - é um dado característico de nossa época. E o Vaticano II reconheceu esse dado: aquele evento conciliar abriu-se para o mundo moderno e para a cultura moderna baseada no pluralismo cultural. Se a igreja católica anterior ao Concílio era uma igreja fechada na cultura da cristandade, no pós-Concílio encontramos uma igreja que reconhece a autonomia das realidades terrestres e que reconhece a existência do pluralismo cultural.

Defendemos neste artigo que sempre existirão, no âmbito da reflexão teológica, temas transversais implícitos ou explícitos para aqueles que fazem teologia. Esses temas transversais estão presentes na caminhada da comunidade cristã e na sociedade onde ela está inserida. A função da autocrítica na teologia é fundamental para permitir que se explicitem os temas transversais e para que a teologia exerça, de fato, a sua tarefa de reflexão crítica sobre a Igreja e sobre o mundo.

\footnotetext{
${ }^{4}$ É importante ressaltar que tanto a noção Povo de Deus como a teologia decorrente dessa noção aparecem em todos os documentos, excetuando-se apenas a Orientalum Ecclesiarum, sobre as igrejas orientais. Sobre o percurso da Lumen Gentium até chegar ao texto, com todos os embates havidos entre os padres conciliares, ver: LOPES (2011)

${ }^{5}$ Temos consciência dos limites e dos riscos da utilização de conceitos em áreas de conhecimento diferentes daquelas onde foram desenvolvidos originalmente. Mesmo assim, entendemos que a noção de transversalidade pode ser bastante útil na teologia.
} 


\section{Vaticano II: tomada de consciência de um novo locus theologicus}

O Concílio Vaticano II foi um evento multifacetário: seus temas e suas grandes afirmações afetaram a igreja católica em diversos âmbitos. O ponto de partida de sua amplitude de temas foi o mundo moderno. Depois de longa trajetória, não sem muitas dificuldades e reações, a igreja católica assumiu, por meio dos padres conciliares, o desafio de levar em conta o mundo moderno que fora anteriormente rejeitado e condenado em diversos momentos pelo magistério. A atitude de rejeição e condenação levou a igreja católica a um isolamento diante do mundo e à construção de um pensamento antimoderno.

Depois de um longo processo em que se deu o esgotamento dessa posição, João XXIII percebeu que era chegada a hora de considerar com seriedade as intuições positivas da modernidade. A sua iniciativa de convocar o evento conciliar por si só propunha uma nova forma de encarar as mudanças. A Gaudium et Spes, documento que procurou apresentar a "Igreja no mundo de hoje", estabeleceu um novo olhar sobre o mundo, indicando que a Igreja, para exercer fielmente sua missão, "tem o dever de perscrutar os sinais dos tempos e interpretá-los à luz do Evangelho, de tal modo que possa responder, de maneira adaptada a cada geração” (4a).

Seguindo a intuição de João XXIII, o Vaticano II inaugurou uma nova leitura do mundo e da própria igreja baseada na ideia de ruptura que, no dizer de Libanio, procura acentuar "a novidade, as modificações, os cortes culturais da história e suas condilões sociais. Volta o olhar para o que está surgindo de original, de diferente...” (LIBANIO, 2005, p. 10). Essa nova leitura permite compreender as mudanças no mundo moderno e na própria igreja, ao contrário da leitura da continuidade, que parte da ideia da imutabilidade para compreender as diversas realidades.

Do ponto de vista epistemológico, foi essa leitura da ruptura (LIBANIO, 2005, p. 10) que possibilitou ao Concílio tomar consciência de um novo locus 
theologicus, o mundo moderno. Ao fazer isso, o Concílio considera a realidade terrestre como ponto de partida para a sua reflexão. Em outros termos, a igreja católica desloca o eixo de sua compreensão: se antes ele estava nela mesma, agora está no mundo. O mundo é o ponto de partida para o discurso da instituição e também para a compreensão do seu lugar e de sua missão. Dessa forma, o Vaticano II dá início a um processo que, na prática, se traduziu no rompimento com a sociedade de cristandade (COMBLIN, 2005, p. 47) e, consequentemente, com a Igreja de cristandade. O mundo moderno é reconhecido como locus theologicus e, portanto, como realidade a partir da qual o fazer teológico é relevante.

Se o Vaticano II fosse um evento destinado apenas a tratar de temas eclesiásticos, não teria tido a importância que teve: foi porque se abriu ao mundo moderno, às realidades terrestres, que o Concílio pôde ser criativo também no âmbito eclesiástico; foi porque se arriscou a conhecer o mundo a partir dele mesmo, perscrutando seus avanços e conquistas e também suas contradições e seus limites, que pôde inovar e apontar novos desafios e novas direções para a igreja católica; foi porque abandonou a atitude de condenação do mundo, tão comum nos discursos do período pré-conciliar, que pôde romper com o modelo de cristandade; em suma, foi porque colocou em segundo plano a perspectiva dogmatista que o Vaticano II foi capaz de construir uma perspectiva hermenêutica (LIBANIO, 2005, p. 75-77).

Essa perspectiva hermenêutica está na raíz da atitude fundamental que perpassou toda a proposta conciliar: o diálogo entendido como esforço "para conhecer e entender o mundo no qual vivemos, suas esperanças, suas aspirações e sua índole frequentemente dramática” (GS 4a). No dizer de Passos, o diálogo "emergia, pois, como caminho inevitável e necessário da postura sobre a qual fundaram o ideal e a realização do Concílio: a colocação da Igreja frente a frente com a sociedade moderna na busca do aggiornamento" (2015, Verbete Diálogo). 
Três aspectos do mundo moderno nos interessam aqui: a diversidade no interior do cristianismo, a diversidade no mundo das religiões e a liberdade religiosa. Esses aspectos estão intrinsecamente vinculados um ao outro. $\mathrm{O}$ mundo moderno reconheceu a importância da diversidade religiosa e viu nascer, a partir da Reforma Protestante, diversas igrejas. A bandeira da liberdade religiosa, tão defendida pelos modernos, historicamente encontrou muita resistência no interior da igreja católica, que via essa novidade como uma ameaça à sua condição de igreja hegemônica.

Para pensar esses temas, os padres conciliares tiveram que percorrer um deslocamento de uma concepção centrada na igreja católica como única e verdadeira para uma concepção que afirma que a Igreja de Cristo subsiste na igreja católica, mas não se identifica com ela. Esse deslocamento permitiu uma postura mais humilde diante das igrejas cristãs e também diante das religiões.

A teologia do ecumenismo e a teologia das religiões assumida pelos padres conciliares estavam em consonância com o caminho do diálogo e respondiam a uma situação: a da diversidade religiosa e do pluralismo religioso ${ }^{6}$. Frente a uma realidade do campo religioso, agora reconhecida como um dado a ser levado a sério, os padres conciliares escolheram um novo lugar para pensar teologicamente e pastoralmente o mundo: o lugar da diversidade e da liberdade religiosa.

Aquilo que para muitos pode gerar perplexidade (TRACY, 2006, p. 11), foi considerado pela maioria dos padres conciliares como um dado positivo. Em outas palavras, o mundo, com toda a sua complexidade, exige da fé cristã e, por consequência, da própria Igreja, um "ato de confiança". Ou seja, uma atitude positiva diante do mundo onde se devem discernir os valores que antecipam o reino de Deus:

\footnotetext{
${ }^{6}$ Entendemos diversidade religiosa como sendo uma realidade social na qual encontramos a presença de diversos sujeitos religiosos (grupos e instituições), enquanto que o pluralismo religioso é uma concepção que considera a diversidade religiosa como um valor e como uma necessidade para a vida social.
} 
devemos reconhecer que a fé cristã, como confiança em e lealdade a Deus e Jesus Cristo, demanda uma confiança fundamental ao mundo em toda a sua ambiguidade. Nos termos mais formais apropriados a essa análise, a fé cristã demandas legítimas por justiça na sociedade e por integridade intelectual na academia (TRACY, 2006, p. 78).

A pergunta a respeito da cultura do pluralismo aventada por esse autor certamente esteve presente na consciência de muitos padres conciliares: "cada tradição deve ao final diluir-se num mínimo denominador comum ou aceitar uma existência marginal como uma opção interessante, mas puramente privada?" (TRACY, 2006, p. 11). Diante desse dilema, o Concílio procurou avançar por outro caminho teológico: o caminho do diálogo com os outros parceiros do mundo religioso.

Nessa perspectiva, o Vaticano II não se furtou a pensar novas questões e novos temas, sobretudo aqueles atinentes ao campo religioso, a partir de um novo locus. Essa mudança já significou um grande movimento, independentemente das implicações que os padres conciliares tiraram do mesmo.

De qualquer forma, as intuições conciliares foram fundamentais para relançar a teologia para um novo locus, para uma nova situação caracterizada pelo pluralismo e, além disso, permitir que essa nova situação "adentre a teologia cristã como uma dimensão histórica intrínseca da própria reflexão" (HAIGHT, 2003, p. 481).

Dois documentos conciliares apresentam-nos a teologia das religiões adotada pelo Concílio: A declaração Dignitatis Humanae e a Declaração Nostra Aetate. Os dois documentos apresentam a concepção dos padres conciliares sobre as religiões: o primeiro trata do fenômeno da liberdade religiosa, tão rejeitado pela igreja católica porque, segundo a visão oficial, solapava o lugar hegemônico da instituição no ocidente; o segundo apresenta os primeiros passos na direção de uma nova compreensão das relações com as religiões. 
Os dois documentos representam uma ruptura com a posição oficial mantida durante quase dois mil anos, de condenação às religiões. Segundo Tamayo, a palavra-chave para compreender a posição da igreja católica diante da modernidade foi "medo" (2004, p. 182). Medo das mudanças trazidas pela modernidade, medo da renovação. Mas, no que se refere às religiões, o medo também foi a palavra-chave que orientou a conduta da igreja católica frente às religiões e aos membros destas. As diversas condenações das religiões e dos seus fiéis - essa mentalidade também foi estendida às igrejas cristãs - tinham como uma das suas razões, o medo.

Nesse sentido, a intenção do Vaticano II ao procurar compreender as religiões com outro paradigma significou um empreendimento gigantesco, que só pode ser avaliado a partir de um olhar sobre os quase dois milênios anteriores de condenações e de silêncio sobre a presença de Deus nas religiões.

Mesmo partindo do pressuposto de que o Vaticano II ficou restrito à posição inclusivista, é preciso admitir que isso representou uma mudança profunda que deu início à elaboração de um novo paradigma. Também no que diz respeito à teologia das religiões, o evento conciliar significou uma ruptura com a cristandade onde tudo o que estava fora das fronteiras da igreja católica era anatematizado (TAMAYO, 2004, p. 186)7.

\section{A pertinência da transversalidade do diálogo inter-religioso}

Wolff (2015), num texto recente, afirma que o ecumenismo é "um elemento transversal no programa de aggiornamento da Igreja conciliar” (p. 209). Por isso, o autor fala na "intenção ecumênica do Concílio" (p. 211) justamente para enfatizar a importância que o ecumenismo teve no conjunto do Vaticano II, como o próprio documento sobre o ecumenismo ressaltou: "a reintegração da unidade entre todos os cristãos é um dos objetivos principais do Sagrado Sínodo Ecumênico Vaticano

\footnotetext{
${ }^{7}$ Acertadamente, Tamayo explica que o modelo de Igreja antes adotado pela igreja católica estava baseado na doutrina agostiniana sobre a "necessidade da graça de Cristo para salvar-se, que excluía toda possibilidade das virtudes nos pagãos" (2004, p. 186).
} 
Segundo" (UR 1a). Esses e outros elementos apontam para o fato de que o ecumenismo foi, de fato, um tema transversal no programa conciliar: o aggiornamento foi assumido na perspectiva do diálogo com as igrejas e ficou sendo sinônimo de diálogo, e o ecumenismo uma de suas expressões mais importantes.

Se o ecumenismo foi seguramente um dos temas transversais do pensamento conciliar, cabe a pergunta: será que o diálogo inter-religioso foi também um desses temas transversais? Apesar dos avanços do Concílio, é necessário responder que, apesar do grande esforço de compreender de forma positiva as religiões, esse tema não chegou a ser transversal aos documentos conciliares.

Se esse tema não foi transversal aos documentos e preocupações conciliares, precisamos nos perguntar: será possível pensarmos, então, para além do Concílio, numa perspectiva de diálogo inter-religioso que seja transversal tanto no âmbito do discurso como no da ação pastoral? Mais do que isso: em que medida o diálogo inter-religioso que tenha o status de transversal pode ser embasado nos documentos conciliares? Se a primeira pergunta, nos leva a pensar se é válido ou não falarmos no caráter transversal do diálogo inter-religioso, a segunda nos obriga a buscar os seus fundamentos.

A resposta à primeira pergunta depende de uma compreensão mais abrangente do fenômeno religioso, do pluralismo religioso e da própria missão. Um dado importante para entendermos esses dois temas está relacionado com uma peculiaridade do mundo moderno: o surgimento da consciência de que a diversidade religiosa é um valor que decorre da própria riqueza da realidade humana e que as religiões, como parte da cultura, manifestam uma das principais características do humano: a diversidade. Passados cinquenta anos do encerramento do Vaticano II, é preciso reconhecer que, sobretudo no mundo ocidental, o fenômeno da diversidade religiosa acelerou. Em algumas sociedades, 
outros fenômenos do campo religioso se tornaram mais intensos por causa dessa diversificação: o campo religioso é uma das realidades sociais onde os "arranjos religiosos" a cada dia se tornam mais intensos. O reflorescimento religioso propicia muitas combinações que podem ser identificadas como resultado de um hibridismo cultural (SOARES, 2010).

Se os padres conciliares tinham consciência de que muito havia mudado no campo religioso ocidental e que a igreja católica não era mais hegemônica e, por isso, precisava adotar uma posição mais compreensiva diante das mudanças religiosas e colocar-se numa atitude de diálogo com as religiões, as mudanças ocorridas no campo religioso nesses últimos cinquenta anos levam a pensar se já não está na hora de se adotar uma atitude mais arrojada.

A segunda pergunta tem a ver com os textos do Concílio, mas, sobretudo, com o seu espírito. Como já dissemos, os dois documentos aos quais já nos referimos nos apresentam uma mudança de paradigma. Foi a primeira vez na história que a igreja católica oficialmente se posicionou positivamente a respeito das religiões. Foi a primeira vez na história que a igreja católica, em decorrência desse posicionamento, estimulou os católicos a dialogarem e cooperarem com os seguidores de outras religiões (NA 2c). Esses documentos procuraram expressar a grande meta do evento conciliar: o diálogo. Nesse sentido, o Vaticano II abriu um caminho importante para a teologia, para a prática pastoral, para a espiritualidade e para a relação dos católicos com os membros de outras religiões. E esse caminho é irreversível para a tradição católica.

No entanto, a própria concepção teológica sobre as religiões que orientava os padres conciliares não permitiu ir além desse caminho aberto. A concepção inclusivista, com base na teoria do "acabamento" e na teoria da "presença de Cristo nas religiões" (TEIXEIRA, 1995, pp. 45-47), naquele momento, era a concepção possível de ser assumida pela igreja católica: ela possibilitou a essa instituição tomar consciência da realidade das religiões e fazer sobre elas uma avaliação positiva. Por outro lado, embora essa posição fosse bastante avançada para a 
época, ela tinha os seus limites por causa da própria concepção teológica assumida, ao contrário do que afirma Vigil: "o concílio não teve tempo de ir mais além” (2006, p. 81) ${ }^{8}$. O limite, portanto, não era o tempo limitado que os padres conciliares tinham para discutir o tema, mas sim a concepção teológica predominante entre os padres. Não é possível exigir que o Concílio tivesse outro posicionamento. O paradigma assumido era o paradigma possível para a época, o que já era um avanço.

Como já foi assinalado neste texto, o diálogo foi uma dimensão constitutiva do pensamento conciliar. De outra forma, foi por causa dessa dimensão que se tornou possível o ecumenismo e a abertura do Vaticano II para as religiões. Não fosse a prioridade dada pelos padres conciliares ao diálogo, não teria sido possível também lançar um olhar positivo e compreensivo às igrejas cristãs e às religiões.

Pensar no diálogo inter-religioso como um tema transversal é refletir sobre as implicações de fazer com que essa teologia adentre o conjunto da elaboração teológica e da prática pastoral9. Nenhuma teologia pode ser feita sem diálogo com três diferentes públicos: a sociedade, a academia e a igreja (TRACY, 2006, p. 23), a despeito de muitos teólogos defenderem que a Igreja deve ser o único público-alvo do fazer teológico; obviamente esse diálogo com esses públicos não deixa a teologia isenta de influências.

No caso específico do público "sociedade", o diálogo obriga a teologia a levar a sério as preocupações da sociedade e de todos aqueles que dela fazem parte. Se o Concílio produz uma teologia do mundo - das realidades terrestres -, a reflexão teológica tem que considerar as necessidades e os apelos da realidade social como sinais dos tempos a serem discernidos pela teologia. Como disse o papa Francisco

\footnotetext{
${ }^{8}$ Em seu livro Teologia do pluralismo religioso. Para uma releitura pluralista do cristianismo, Vigil acrescenta que o Concílio "não questionou se era possível afirmar que as próprias religiões não cristãs são caminhos de salvação para seus membros por si mesmas, e não por uma participação sua no mistério de Cristo" (2006, p. 81).

${ }^{9}$ A incidência do diálogo inter-religioso nas práticas das igrejas cristãs só será possível na medida em que elas se envolvam, de fato, nas iniciativas concretas de diálogo inter-religioso. Isso significa sair do discurso e ir para a prática concreta do diálogo inter-religioso, sair da palavra é ir para a ação.
} 
ao cardeal Mario Aurelio Poli, Grão-Chanceler da Universidad Católica Argentina, por ocasião do centenário da Faculdade de Teologia daquela universidade,

ensinar e estudar teologia significa viver numa fronteira na qual o Evangelho se encontra com as necessidades das pessoas às quais é anunciado de maneira compreensível e significativa. Devemos evitar uma teologia que se esgota na disputa académica ou que olha para a humanidade de um castelo de vidro (FRANCISCO, Carta por ocasião do centenário da Faculdade de Teologia da Pontifícia Universidade Católica Argentina).

Por outro lado, no próprio interior da teologia é necessário o diálogo entre as várias disciplinas. Sendo assim, propor que o diálogo inter-religioso adentre o cenário teológico é levar adiante esse caráter dialógico da teologia que está presente no seu nascedouro e na sua destinação (KNITTER, 2010, p. 189).

Uma teologia que fundamente o diálogo inter-religioso não deve ser competente apenas para dialogar com as demais disciplinas; ela deve ser competente também para tornar-se, assim como a teologia do ecumenismo, uma teologia transversal, que perpassa as várias disciplinas da teologia e a ação pastoral.

Algumas razões que justificam assumir o diálogo inter-religioso como transversal estão relacionadas tanto aos textos fundadores do próprio cristianismo como também ao contexto histórico em que vivemos.

\section{Modos da transversalidade do diálogo inter-religioso}

Ao falarmos na necessidade da transversalidade do diálogo inter-religioso, é necessário apontar os diferentes modos em que essa transversalidade pode se efetivar. Como já afirmamos, a transversalidade do diálogo inter-religioso deve se dar em todas as áreas da teologia e da pastoral: ela deve ser levada em conta no âmbito da elaboração teológica, na espiritualidade e na organização da atividade pastoral. Não se trata de apenas eleger alguns temas que facilitem a reflexão teológica a partir do e em relação com o diálogo inter-religioso. Trata-se de 
possibilitar que a reflexão oriunda do diálogo inter-religioso, com os seus temas e seus insights, perpasse toda a teologia. Em outras palavras, trata-se de assumir a perspectiva do diálogo inter-religioso como uma das preocupações constituintes e constantes da construção teológica.

Num mundo plural, como é aquele em que vivemos hoje, é preciso reconhecer que as igrejas cristãs são parte da diversidade religiosa. Esse pressuposto, por si só, já aponta para uma nova forma de compreender o lugar do diálogo inter-religioso na vida das igrejas nos tempos atuais ${ }^{10}$.

Neste texto, queremos enfatizar algumas áreas da vida das igrejas cristãs que são prioritárias para promover a transversalidade do diálogo inter-religioso. Identificamos quatro áreas: missão, liturgia, catequese e educação teológica. A escolha dessas quatro áreas está relacionada com três elementos que são inerentes à vida das igrejas: ação no mundo, celebração dos conteúdos da fé cristã e a formação da consciência cristã.

\section{a) Missão}

A escolha por começar com a missão tem a ver com o próprio lugar que a missão ocupa na igreja cristã. Ela faz parte da essência da Igreja, é a sua razão de ser no mundo:

essência da vida da Igreja é justamente aquilo que nela está relacionado com o "para quê" de sua existência. O que justifica a ação da Igreja no mundo são os motivos que definem a sua razão de ser. Assim, a missão constitui o "para quê" da vida da Igreja e é, portanto, a própria essência da vida da Igreja. A Igreja existe para a missão. (SANCHEZ, 2013, p. 116).

\footnotetext{
${ }^{10}$ Embora esse caminho ainda possa ser considerado tímido, é inegável que têm acontecido iniciativas que estão aproximando as religiões. Tanto na convivência das pessoas no seu cotidiano - nos diversos espaços de vida -, como entre as lideranças das religiões e entre os seus teólogos, o diálogo tem-se dado. A esse respeito ver Wagner Lopes SANCHEZ, Vaticano Il e o diálogo inter-religioso.
} 
Nas palavras do Vaticano II, a missão constitui a natureza da Igreja e, portanto, é constitutiva da mesma: “A Igreja peregrina é por sua natureza missionária. Pois ela se origina da missão do Filho e da missão do Espírito Santo, segundo o desígnio de Deus Pai” ( $A G$ 2).

Kahler tem razão quando afirma que a missão é a "mãe da teologia" (apud BOSCH, 2002, p. 34). A missão é a razão de ser da Igreja e também da própria reflexão teológica. Ao mesmo tempo em que a missão é a razão de ser, temos que reconhecer também que a missio Dei ultrapassa a própria Igreja. As religiões também são missionárias ou, no dizer de Knitter, elas são também "agentes do reino" (2010, p. 148), pois a missão não é da Igreja ou de uma religião, mas é missio Dei, missão do próprio Deus, e transborda para todas as religiões. Por isso, é de fundamental importância reconhecer

que a missão ... ultrapassa a própria Igreja e se estende a todas as religiões e todos os homens/mulheres que se comprometem com a justiça e a vida. Para a realização da atividade missionária há um grande 'mutirão de Deus' sendo desenvolvido na história (SANCHEZ, 2013, pp. 142-143).

Isso nos obriga a pensar a missão para além do proselitismo que, durante muito tempo, foi a preocupação central da atividade missionária das igrejas cristãs. Se o próprio diálogo, ao lado do anúncio, é um dos componentes da missão, como afirma o Documento Diálogo e Anúncio (2), de 1991, o diálogo inter-religioso deve ser assumido como uma prioridade. Knitter procura avançar para além da ideia de o diálogo fazer parte da missão. Ele propõe a inversão desses termos:

em vez de tentar incluir o diálogo na missão, teria mais sentido incluir a missão no diálogo - ou entender a missão como diálogo. Hoje em dia, missão poder compreendida como e praticada como diálogo. Ou seja, a melhor forma como a Igreja pode servir ao Reino de Deus, no mundo atual... é por meio do diálogo (KNITTER, 2010, p. 175).

A reflexão de Knitter está em coerência com a ideia de que Deus se revela à humanidade se comunicando e permite perceber a missão muito além de atividades consideradas missionárias: 
definir a missão da Igreja como diálogo não é reduzir essa missão a alguma atividade específica, mas antes ampliar essa missão além das atitudes e práticas tradicionais e equilibrar melhor vários aspectos da missão. Considerar e praticar a missão como diálogo é considerar a missão da Igreja essencialmente como uma missão de comunicação (KNITTER, 2010, p. 177).

É necessário aprofundar a dimensão dialógica da evangelização e assumir que todas as religiões, de diferentes modos misteriosos, participam do anúncio do reino de Deus. Temos de reconhecer o avanço do Concílio em relação às religiões; no entanto, é preciso ir além das suas intuições. Um caminho para ir além dessas intuições é reconhecer que a noção de missão precisa ser revista e inserida no novo contexto do campo religioso e na nova consciência a respeito da riqueza presente nas religiões. Aceitar que as religiões também são missionárias do reino de Deus pode proporcionar uma mudança tanto na auto-compreensão da igreja católica como na sua concepção de missão. Não se trata de abrir mão de anunciar o reino, mas reconhecer que existem muitas outras religiões que também são partícipes desse anúncio.

Knitter fala da necessidade de uma "visão correlacional" (2010, p. 133) sobre as religiões; podemos falar também na necessidade de uma "visão correlacional" sobre a própria atividade missionária; ela não pode ser vista de forma exclusiva e nem excludente, mas correlacionada com a missão das religiões. Cada uma delas procura responder, a partir de seus diferentes contextos culturais e de suas tradições, aos apelos de Deus, que se revela de forma misteriosa à humanidade.

O papel das igrejas cristãs na atividade missionária é de contribuir para que o reino de Deus triunfe, e não as suas estruturas. Colocar-se numa atitude de despojamento à semelhança de Jesus ( $\mathrm{cf} \mathrm{Fl} \mathrm{2,6-11)} \mathrm{é} \mathrm{sinal,} \mathrm{justamente,} \mathrm{do} \mathrm{reino} \mathrm{de}$ Deus, é sinal de que o reino de Deus é absoluto (KNITTER, 2010, p. 140). As igrejas - e as religiões também -, com suas doutrinas e suas estruturas, perecem; o reino de Deus é permanente e transcende a própria história. 
Portanto, na atividade missionária revista à luz do diálogo inter-religioso, o reino é a prioridade da comunidade eclesial e também da missão: se a razão de ser da Igreja é a missão - e isso é consenso entre as igrejas cristãs -, a razão de ser da missão é o reino de Deus. E isso não significa abrir mão de outros objetivos da missão:

A fim de promover o reino, os missionários devem ocupar-se de muitas coisas, tais como plantar a ecclesia, estabelecer a comunidade, proclamar a Palavra, dialogar com outras comunidades de fé. Precisamos dizer que todas estas tarefas são essenciais ${ }^{11}$ para o propósito da missão. Mas ao insistirmos que elas são essenciais, reconhecemos que estão subordinadas ao objetivo principal e central de trabalhar pelo Reino. São meios essenciais para o fim principal, mas nunca podem se tornar fim em si mesmas (KNITTER, 2010, p. 140).

Considerar a missão com esse novo olhar, é fazer com que o diálogo interreligioso deixe de ser apenas uma atividade, para ser uma nova perspectiva, uma perspectiva transversal que perpasse e dê vida à atividade missionária. A transversalidade do diálogo inter-religioso na atividade missionária será possível na medida em que as igrejas cristãs:

- reconheçam, em sinal de humildade, que fazem parte do mundo das religiões e que, por isso, não têm privilégios ou prerrogativas;

- assumam o diálogo inter-religioso como prioridade e incorporem às atividades missionárias as diversas ações possíveis nesse âmbito;

- reelaborem sua mensagem, levando em conta tanto a pluralidade das religiões existente como o pressuposto de que as religiões, de certa forma, são co-partícipes na missio Dei. Neste caso, a linguagem utilizada para exprimir a mensagem cristã não pode ser ofensiva às crenças e aos valores das outras religiões;

- anunciem o reino de Deus como a grande novidade de Jesus.

\footnotetext{
${ }^{11}$ Itálico do próprio Knitter.
} 


\section{b) Liturgia}

A liturgia é a face mais exposta da comunidade cristã. Não é por acaso que quando se pergunta ao povo pelas mudanças desencadeadas pelo Concílio Vaticano II, a primeira que é indicada é a da liturgia. Justamente por externalizar os mistérios da fé cristã, a liturgia é a grande manifestação da vida da Igreja ao público e à sociedade.

Em virtude de seu caráter público, a liturgia revela o que está no profundo do imaginário dos cristãos. A mudança da consciência eclesial na direção do diálogo inter-religioso tem na liturgia o momento da sua maior visibilização. Por isso, há que se cuidar com muito empenho da liturgia, levando em conta as exigências do diálogo inter-religioso.

A liturgia é a expressão da fé eclesial, como dizia Próspero de Aquitânia, no século V: "lex orandi, lex credendi" (MEYNDORFF, 2005, p. 727). Inclusive, como lembra Meyendorff, a liturgia chegou a ser fonte de teologia, sobretudo a partir do século IV, com o aumento do número de cristãos por causa das medidas constantinianas (2005, p. 727). Independentemente das diferentes tradições no interior do cristianismo, em todas elas esse aspecto é fundamental: a liturgia é a expressão daquilo que a Igreja crê.

A expressão dos vários símbolos e expressões litúrgicas precisa considerar que as comunidades cristãs, ao celebrarem suas liturgias, fazem-no ao mesmo tempo em que outras religiões prestam culto a Deus. Não se trata de abrir mão dos símbolos e expressões próprias de cada tradição cristã, mas de evitar que eles agridam a sensibilidade das outas religiões e dos seus membros.

A liturgia pode ser espaço privilegiado para que os cristãos experienciem e alimentem uma espiritualidade centrada no diálogo e aberta ao pluralismo religioso ou, como dirá Vigil, uma "espiritualidade do pluralismo religioso" (VIGIL, 
2006, pp. 374-393). A celebração da fé cristã pode ser também a celebração de uma fé aberta e sensível a outras formas de crer e de adorar a Deus, já que, no cristianismo, celebrar os mistérios da fé é, ao mesmo tempo, celebrar a vida vivida em meio a um mundo plural. Uma liturgia que esteja voltada apenas para a comunidade que celebra é uma liturgia que alimenta o fechamento e o isolamento num mundo no qual o diálogo é afirmado como caminho de convivência entre as pessoas.

\section{c) Catequese}

Uma igreja que tenha em conta uma visão correlacional sobre as religiões precisa preparar os seus membros para serem acolhedores com os membros de outras religiões e, sobretudo, para terem uma compreensão mais acolhedora sobre suas religiões. Os vários tipos de catequese têm, então, um papel importante no sentido de formar o público das comunidades cristãs para conhecerem as outras religiões e seus conteúdos.

Ao mesmo tempo em que a catequese deve transmitir àqueles que se preparam para os sacramentos os conteúdos da fé cristã relidos a partir de cada tradição, ela deve também ter a preocupação de preparar os cristãos a se abrirem para a diversidade religiosa, para a riqueza religiosa das outras religiões e para a cooperação com pessoas e grupos de outras religiões.

A catequese deve, em última instância, preparar os cristãos para também reconhecerem nas outras religiões as suas riquezas e seus valores, mesmo quando não convirjam com os conteúdos da fé cristã. Além disso, é preciso alimentar nos cristãos a sensibilidade para aprender com os outros, para descobrir outras formas da presença de Deus nas religiões e, dessa forma, fortalecer a sua fé cristã.

No mundo da diversidade religiosa, há muito as pessoas convivem no seu cotidiano com membros de outras religiões, frequentam seus espaços religiosos e elaboram suas sínteses religiosas em suas vidas, apesar do fato de as lideranças 
religiosas muitas vezes discordarem disso. Em certo sentido, já existe um diálogo implícito na vida das pessoas. Agora, é necessário capacitar os cristãos para que possam dialogar explicitamente, aprendendo com os outros.

A preparação para os sacramentos, ressaltando os da iniciação cristã, é oportunidade para rever a concepção exclusivista do cristianismo, mostrando que essa grande tradição, ao longo de sua trajetória, promoveu o diálogo com outras religiões e que, mesmo com posições oficiais exclusivistas, sempre houve espaço para a convivência harmoniosa com outras tradições espirituais. Os diversos tipos de sincretismos no interior do cristianismo são exemplos disso. De outra forma, o cristianismo atual é resultado de um grande sincretismo (VIGIL, 2006, p. 429430).

Aproveitar esse "espírito sincrético" presente nas várias modalidades de cristianismo é caminho para tornar os cristãos mais abertos e mais compreensivos.

\section{d) Educação teológica}

A educação teológica é aquela que é destinada a um público das comunidades cristãs que busca aprofundar sua fé com o instrumental da reflexão teológica. Nas igrejas cristãs, na maioria das vezes a educação teológica - com suas faculdades e seus institutos de teologia - é destinada, prioritariamente, a quem vai assumir os ministérios eclesiais.

A educação teológica, nos seus componentes e estrutura curriculares e nos seus métodos, há que adotar uma linguagem que considere o diálogo interreligioso como uma prioridade. $\mathrm{O}$ estudo dos diferentes aspectos da tradição teológica de cada igreja terá o tema do diálogo inter-religioso como um tema transversal. 
Além disso, os estudantes de teologia, inclusive aqueles que são candidatos aos ministérios eclesiais, terão que ser educados para o diálogo inter-religioso. Se tradicionalmente esses estudantes foram preparados para assumir uma postura de defesa do exclusivismo em relação às religiões e em relação às igrejas cristãs (KNITTER, 2010, p. 56), agora terão que ser capacitados para o diálogo intra e inter-religioso para lidar com a realidade do pluralismo.

Um caminho possível seria possibilitar e incentivar a presença de professores e de autores de outras tradições religiosas, o que enriqueceria a formação teológica com base no pluralismo teológico.

A produção teológica se enriquece com a adoção da realidade do pluralismo religioso como locus para a reflexão teológica.

\section{Para um novo locus theologicus uma nova exigência: a transversalidade.}

Olhar o mundo a partir da diversidade religiosa ajuda-nos a compreender outros aspectos da realidade social: ela desponta para nós como lugar privilegiado do pluralismo, onde encontramos o outro e aprendemos com ele. Entendemos que para a igreja católica - e também para as igrejas cristãs -, um olhar compreensivo para a diversidade religiosa pode contribuir não só com a sua auto-compreensão, mas também com a realização de sua missão.

O reconhecimento de que o mundo das religiões é bastante diverso e de que as igrejas fazem parte dele, obriga a releitura da mensagem cristã a partir de novos contextos socioculturais. Esse foi um dos apelos do Vaticano II: considerar o mundo como ponto de partida para a compreensão do lugar e da tarefa da Igreja.

A construção da reflexão teológica a partir do locus do pluralismo religioso traz desafios enormes às igrejas. Um desses desafios é perceber que, no contexto atual, o pluralismo religioso perpassa o mundo das religiões. Ele está presente não só na própria existência de uma multiplicidade de religiões, mas também dentro 
das próprias religiões em virtude da diversidade que marca a convivência social. Por mais refratárias que pretendam ser à diversidade religiosa e ao contato com as demais, as religiões têm que admitir que, no seu interior, acontecem diferentes arranjos religiosos promovidos pelos seus membros que muitas vezes fogem do controle de suas lideranças. Esses arranjos, de diferentes formas e com diferentes matizes, modificam as religiões ao longo do tempo; é um grande processo de sincretização. E nenhuma religião está livre desse processo (KLINGER, 2010) ${ }^{12}$.

Em certo sentido, a esse fenômeno de sincretização das e nas religiões, aplica-se o conceito de transversalidade que utilizamos neste texto. O sincretismo é um fenômeno que aponta para uma transversalidade implícita. Na sua convivência com outros membros das religiões, nas suas aproximações com as religiões e nos seus arranjos religiosos, as pessoas já realizam, em suas vidas, a transversalidade de temas religiosos que, embora possam ficar na penumbra, contribuem para construir sentido em suas existências.

Assumir o tema do diálogo inter-religioso como transversal significa: a) construir uma nova abordagem da teologia - e não apenas a inclusão de uma ou outra disciplina teológica -, que considere a legitimidade do pluralismo religioso e das próprias religiões existentes, eliminando todo resquício de exclusivismo; e b) promover uma pastoral mais orgânica, centrada no diálogo como uma dimensão inerente à vida da Igreja; assim como Deus salva comunicando-se à humanidade, dialogando com ela, assim também a atuação da Igreja no mundo deve ser feita na dinâmica do diálogo. A pastoral deve, portanto, ser expressão desse diálogo com a sociedade.

\footnotetext{
${ }^{12}$ Referindo-se ao cristianismo, Klinger chega a dizer que "o sincretismo fundamenta o cristianismo e lhe concede identidade religiosa na cultura de um mundo estranho" (2010, p. 44).
} 


\section{Conclusão}

Um exame atento da história do cristianismo revela que o que se denomina de a identidade cristã é plural (KLINGER, 2010, p. 112), constituída de elementos diversos oriundos das diversas culturas onde vivem os cristãos. Se podemos falar em uma identidade cristã, é preciso insistir que ela não é livre de influências. Os fenômenos da enculturação da fé e do sincretismo são exemplos disso. Se isso ocorre com o cristianismo, ocorre também com todas as religiões.

Num contexto de pluralismo religioso, as relações estabelecidas pelas religiões com as demais sempre conduzirão a uma "contaminação" recíproca decorrente das próprias relações estabelecidas pelas pessoas, como já assinalamos neste texto.

A insistência que fizemos neste texto a respeito da transversalidade do diálogo inter-religioso aponta para a necessidade de se dar uma relevância ao diálogo que vá muito além de estratégias de aproximação das igrejas cristãs com as demais religiões. A transversalidade desse tema exige novas abordagens teológicas, mas também novas práticas.

Afirmar a necessidade da transversalidade do diálogo inter-religioso exige novos temas e novas ações, mas também um compromisso renovado com a luta pela justiça e pela paz. O diálogo inter-religioso precisa deixar de ser apenas uma estratégia de convivência entre as religiões para tornar-se uma dimensão fundamental nas suas relações e na forma como realizam suas missões. Só dessa forma as religiões poderão contribuir com a construção de outro mundo possível. 


\section{REFERÊNCIAS:}

BOSCH, David J. Missão transformadora. Mudanças de paradigma na teologia da missão. 3. ed. São Leopoldo: EST-Sinodal, 2009.

BOVO, Marcos Clair. Interdisciplinaridade e transversalidade como dimensões da ação pedagógica. In: Revista Urutagua , Maringá: UEM, n. 7, p. 1-11, 2003.

COMBLIN, José. A teologia das religiões a partir da América Latina. In: TOMITA, Luiza E. BARROS, Marcelo e VIGIL, José Maria, Pluralismo e libertação. Por uma teologia latino-americana pluralista a partir da fé cristã. São Paulo: ASETT-Loyola. p. 47, 2005.

COMBLIN, José. O povo de Deus. São Paulo: Paulus, 2001.

FRANCISCO. Carta por ocasião do centenário da Faculdade de Teologia da Pontifícia Universidade Católica Argentina. Disponível em:

<https://w2.vatican.va/content/francesco/pt/letters/2015>. Acesso em 01/o6/2015.

GALLO, Silvio. Conhecimento, transversalidade e currículo. S/d. Disponível em:

<http://www.academia.edu/518339/Conhecimento_transversalidade_e_curr\%C3\%ADcu lo>. Acesso em: 20 dez. 2015.

HAIGHT, Roger. Jesus, símbolo de Deus. São Paulo: Paulinas, 2003.

KLINGER, Elmar. Jesus e o diálogo das religiões. Aparecida: Santuário, 2010.

KNITTER, Paul F. Jesus e os outros nomes. Missão cristã e responsabilidade global. São Bernardo do Campo: Nhanduti, 2010.

LIBANIO, João Batista. Concílio Vaticano II. Em busca de uma primeira compreensão. São Paulo: Loyola, 2005.

LOPES, Geraldo. Lumen Gentium. Texto e comentário. São Paulo: Paulinas, 2011.

MEYENDORFF, Paul. Verbete "Liturgia". In: LOSSKY, N. et al. (Ed.). Dicionário do Movimento Ecumênico. Petrópolis: Vozes, 2005.

MORENO, Montserrat, Temas transversais: em ensino voltado para o futuro. In: BUSQUETS, Maria Dolors et al. Temas transversais em educação. Bases para uma formação integral. São Paulo: Ática. p. 19-6o.

PASSOS, João Décio. Verbete “Diálogo”. In: PASSOS, João Décio; SANCHEZ, Wagner Lopes. Dicionário do Concílio Vaticano II. São Paulo: Paulus, 2015. 
PONTIFÍCIO CONSELHO PARA O DIÁLOGO INTER-RELIGIOSO-

CONGREGAÇÃO PARA A EVANGELIZAÇÃO DOS POVOS. Diálogo e Anúncio. Disponível em:< http://www.vatican.va.Vaticano: 1991>. Acesso em: 19 jun 2015.

QUEIRUGA, Andrés Torres. O diálogo das religiões. São Paulo: Paulinas, 1997.

SANCHEZ, Wagner Lopes. Teologia da cidade. Relendo a Gaudium et Spes. Aparecida: Santuário, 2013.

SANCHEZ, Wagner Lopes. Vaticano II e o diálogo inter-religioso. São Paulo: Paulus, 2015 .

SEGUNDO, Juan Luis. O homem de hoje diante de Jesus de Nazaré. I. Fé e ideologia. São Paulo: Paulinas, 1985.

SOARES, Afonso Maria de Ligório. Sincretismo e teologia interconfessional.

Ciberteologia - Revista de Teologia \& Cultura, ano VI, n. 27, São Paulo: Paulinas, 2010. Disponível em: <http://ciberteologia.paulinas.org.br/ciberteologia >. Acesso em: 25 jul. 2015 .

SUESS, Paulo. Introdução à Teologia da Missão. Convocar e enviar: servos e testemunhas do Reino. Petrópolis: Vozes, 2007.

TAMAYO, Juan José. Fundamentalismos y diálogo entre religiões. Madrid: Trotta, 2004.

TEIXEIRA, Faustino. Teologia das religiões. Uma visão panorâmica. São Paulo: Paulinas, 1995.

TRACY, David. A imaginação analógica. A teologia cristã e a cultura do pluralismo. São Leopoldo: Unisinos, 2006.

VIGIL, José Maria. Teologia do pluralismo religioso. Para uma releitura pluralista do cristianismo. São Paulo: Paulus, 2006.

VIGIL, José Maria. Identidade cristã e teologia do pluralismo religioso. In: VIGIL, José M.; TOMITA, Luiza E.; BARROS, Marcelo (Org.). Teologia pluralista libertadora intercontinental. Panamá-São Paulo: ASETT-Paulinas, 2007. pp. 137-160.

WOLFF, Elias. O ensino ecumênico do Concílio Vaticano II. In: BRIGHENTI, Agenor e ARROYO, Francisco M. (Org.). O Concílio Vaticano II. Batalha perdida ou esperança renovada? São Paulo: Paulinas, 2015.

WOLFF, Elias. Unitatis Redintegratio. Dignitatis Humanae. Nostra Aetate. Textos e comentários. São Paulo: Paulinas, 2012. 